\title{
Contribution to age determination of pikas (Lagomorpha, Ochotonidae, Ochotona)
}

\begin{abstract}
Andrey A. Lissovsky
ABSTRACT. The possibility of age determination of pikas using tooth row condition, development of crests on the angular process of the dentary, ossification of the skull and development of the skull crests, as well as condition of the reproductive system is discussed. Age variability of the features above is described. The methods allow determining individual age of pikas up to about four months old. Subsequently, morphological differences between specimens born this year and over wintered ones become obscured, but some difference in skull proportions may be retained for some time.
\end{abstract}

KEY WORDS: Ochotona, age determination.

Andrey A. Lissovsky [andlis@zmmu.msu.ru], Zoological Museum of Moscow State University, Bolshaya Nikitskaya ul. 6, Moscow 125009, Russia.

\section{Определение возраста пищух (Lagomorpha, Ochotonidae, Ochotona)}

\begin{abstract}
А.А. Лисовский
РЕЗЮМЕ. Обсуждается возможность определения возраста пищух по состоянию зубного ряда, развитию гребней на угловом отростке нижней челюсти, окостенению и развитию гребней черепа, состоянию половой системы. Описывается возрастная изменчивость этих признаков. Существующие методики позволяют оценить возраст пищухи до четырех месяцев. Позднее морфологические различия между сеголетками и взрослыми пищухами стираются, однако разница в пропорциях черепа еще некоторое время может сохраняться.
\end{abstract}

КЛЮЧЕВЫЕ СЛОВА: Ochotona, определение возраста.

\section{Introduction}

The method allowing determining the exact age of pikas is not elaborated yet. Existing methods enable either to calculate the number of years by the number of cement lines in the periostal zone of the mandible (Bernstein \& Klevezal, 1965; Millar \& Zwickel, 1972) or to distinguish a wintered pika from a young one by the expression of crests on the angular process of the dentary (Khmelevskaya, 1961; Bernstein, 1964; Bernstein \& Klevezal, 1965). Other authors proposed different methods of age determination: by the number of furrows on the claws of the forefoot (Yurgenson, 1939), by the condition of pelage (Tarasov, 1950), or by the condition of mammae and reproductive system (Kapitonov, 1961).

All of the methods were tested by Gashev (1966) on the sample ofO. hyperborea from Polar Ural. He showed, that the method of age determination by the number of furrows on the claws is not effective, due to unclear expression of this feature (see also Bernstein \& Klevezal, 1965), its states having no strong correlation with the age of the animal.

According to the opinion of Gashev (1966), age determination by the expression of crests on the angular process of the dentary, as well as by the degree of skull ossification is possible only up to the fifth month. In this age adult and subadult northern pikas become indistinguishable by these features. The number of cement lines in the periostal zone of mandible does not allow determining the exact age either. On the one hand, various parts of mandible may have different number of lines. On the other hand, the strong correlation between the number of lines and age is absent. Differences in the condition of the reproductive system and mammae between adult and subadult specimens are evident only during a short time and completely disappear by September. Gashev (1966) considered that age determination by the condition of pelage is impossible because of simultaneous molt of adult and juvenile pikas. In the opinion of Gashev (1966), the condition of tooth rows is the best indication of age. Replacement of premolars terminates in the second month of life. Replacement of teeth in the mandible takes the lead over those in the maxilla. Replacement of the inner pair of incisors terminates by the third month of life. At the same time, age variation in dentition of pikas was described only superficially (Gashev, 1966; Gureev \& Erbaeva, 1975; Rekovets, 1985) and there is a number of contradictions in the cited papers.

The basic goal of this investigation is to estimate the validity of various methods for age determination of 
pikas. I did not examine the number of furrows on forefoot claws, because I could not find the explicit demonstration of it in the majority of specimens. I did not examine the number of cement lines in the periostal zone of mandible also, because this method is quite labor-consuming and requires damaging museum specimens.

\section{Material and Methods}

Skulls of pikas of different ages housed in Zoological Museum of Moscow State University (ZMMU) were studied. The following species were investigated: Ochotona alpina (Pallas, 1773) $(\mathrm{n}=170)$, O. hyperborea (Pallas, 1811) $(\mathrm{n}=130)$, O. pallasi (Gray, 1867) $(\mathrm{n}=105)$, O. dauurica (Pallas, 1776) $(\mathrm{n}=225)$, O. pusilla (Pallas, 1769) $(\mathrm{n}=57)$, and O. rufescens (Gray, 1842) $(\mathrm{n}=60)$. Original data of post-mortem examination of $O$. alpina $(\mathrm{n}=30), O$. hyperborea $(\mathrm{n}=30)$, and $O$. turuchanensis $(\mathrm{n}=31)$ were used.

\section{Results}

The crest on the mandible for attaching $\mathrm{m}$. masseter lateralis profundus (Fig. 1) is situated on the lateral side of the angular process on the dentary. This crest in juvenile specimens of analyzed species is not expressed; there is just a roughness on its place. Subsequently the crest appears, but its edges are rounded. With time, the crest becomes clearly prominent, with a readily visible sharp edge. Specimens with undeveloped crest are common during summer and autumn; subsequently, their proportion decreases and practically all winter specimens have a well developed crest. In different samples

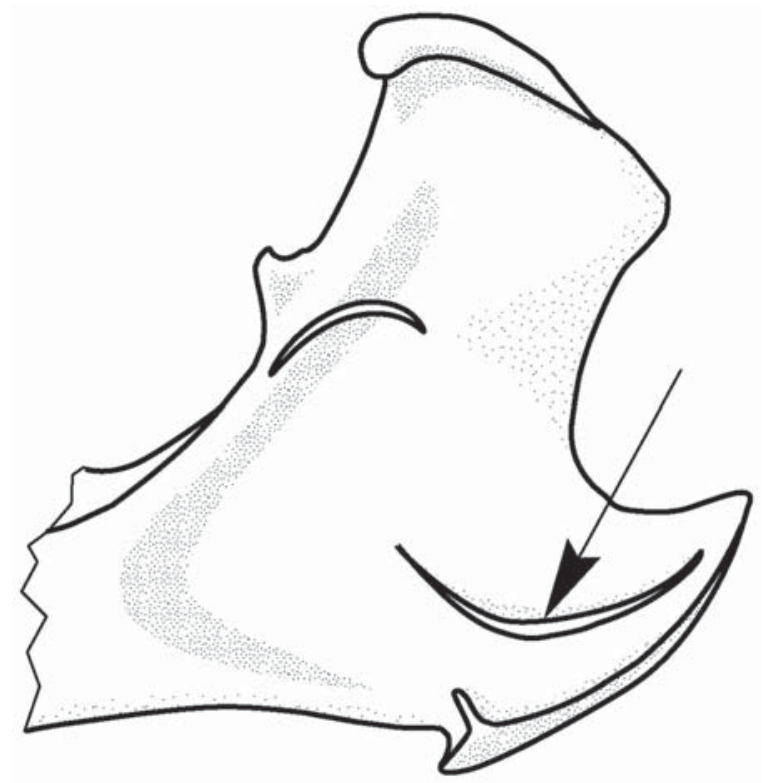

Figure 1. Posterior part of the dentary of Ochotona alpina in lateral view. Arrow points to the crest for attaching $\mathrm{m}$. masseter lateralis profundus. of O. alpina and O. hyperborea collected in November $(n=6)$ only a single specimen with undeveloped crest was found. This feature was not found among December specimens $(n=20)$. Specimens of the other species collected during the winter period are sporadic in the ZMMU collections. The samples of $O$. pallasi collected in October $(\mathrm{n}=4)$, O. dauurica - in January and February $(\mathrm{n}=3)$, and $O$. rufescens - in November-February $(n=5)$ contain only specimens with developed crests.

The development of crests on the medial side of the dentary angular process for attaching $\mathrm{m}$. pterygoideus takes place simultaneously with the previous crest or with a slight temporal shift.

I found the museum specimens with three upper premolars, two lower premolars and the second pair of upper incisors in the state of replacement. The following sequence of replacement could be observed in the studied specimens of $O$. hyperborea $(\mathrm{n}=3), O$. dauurica $(\mathrm{n}=3)$, O. pusilla $(\mathrm{n}=5)$ and $O$. rufescens $(\mathrm{n}=6)$, deciduous teeth of which are in the process of replacement. At first, p4 begin to erupt, then with a little delay or synchronously - p3 and P4. Later, P3 and P2 become replaced one after another. There is some variation in the order of replacement, but the following sequence reflects all the variants in full: $\mathrm{p} 4-(\mathrm{p} 3-\mathrm{P} 4-\mathrm{P} 3)-\mathrm{P} 2$. Replacement of the second pair of upper incisors takes place either prior to the all premolars or synchronously with $\mathrm{p} 4$ and $\mathrm{p} 3$. Permanent incisor begins to erupt from beneath and from the lingual side of the deciduous tooth. Gradually increasing in size the permanent incisor destroys the deciduous one and pushes it aside to the posterior surface of the anterior incisor. At the final stage of replacement the deciduous incisor looks like a small narrow wedge clutched between the first and the second permanent incisors.

It is reasonable to consider the replacement of premolars, as exemplified by $\mathrm{p} 3$. This tooth is most often used for the diagnostics in pikas, including fossil material, making the understanding of its age variation quite significant.

A new-born pika has a three-segmented deciduous lower premolar dp3 (Gureev \& Erbaeva, 1975; Rekovets, 1985) (Fig. 2A). The erupting permanent tooth pushes out the deciduous one from beneath, but the final shedding of the deciduous tooth is delayed until the complete development of the replacing tooth. At this time the base of the crown of the deciduous tooth remains as three long stems (one anterior and two posterior), covered with enamel, closely adjacent to the permanent tooth. Thus, when the milk tooth holds no longer on the crown of the permanent one and falls away, there is a new quite formed tooth with unworn occlusal surface in its place.

The crown pattern of an unworn permanent tooth differs from that of adults (Fig. 2B). Its middle segment looks as a protuberance, while the anterior one is a prominent area situated at a lower level then the other two segments. The posterior part is a concave area. The middle and posterior segments are still divided by enamel loops from both buccal and lingual sides. At this stage, 

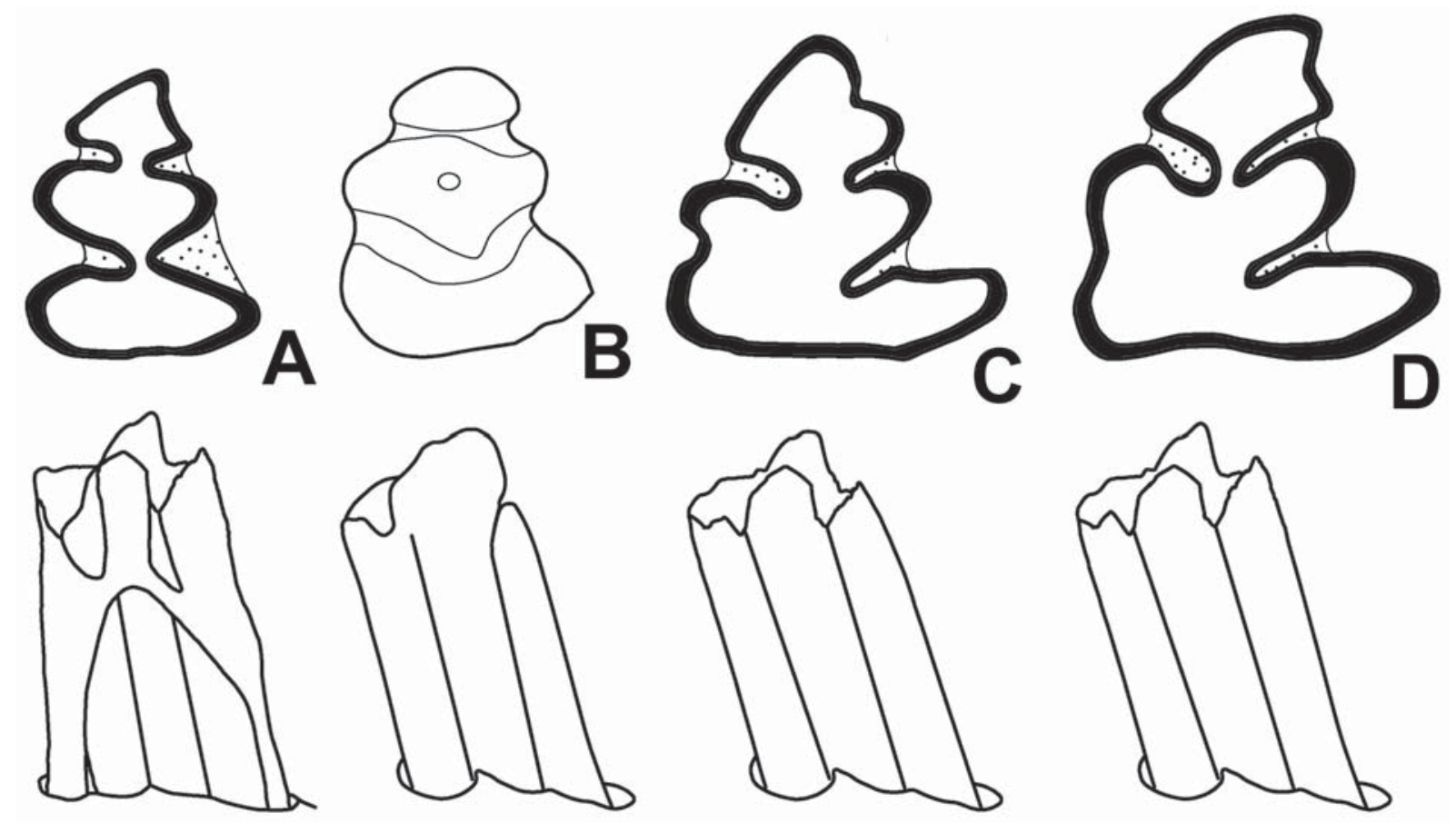

Figure 2. The third lower premolar (dp3 or p3) in pikas in occlusal view (top, enamel of worn tooth is shown by black, cement by dots) and in buccal view (bottom, outlines of the crown).

A - deciduous tooth before generation replacement; B - unworn permanent tooth; C - permanent tooth of pika about three months old; $\mathrm{D}$ - tooth of adult pika.

the tooth crown is tapering towards its apex. The lingual fold between middle and posterior segments is less expressed near the base of the crown than at the crown's apex. Later, the conical part wears out, and subsequently the tooth becomes prismatic with a parallel-sided crown. Wearing out of the prismatic part of the crown occurs simultaneously or a little earlier than the formation of the crest for attaching $\mathrm{m}$. masseter lateralis profundus.

The main diagnostic feature of the $\mathrm{p} 3$ is the structure of its occlusal surfaces. Obviously, as the crown has initially a conical structure, permanent abrasion of the enamel leads to persistent enlargement of the wearing areas. As the prismatic part of the tooth becomes worn, the linear measurements and the occlusal surface become stable.

Conversion of the crown to its definitive prismatic state is accompanied by the disappearance of the lingual fold between its middle and posterior segments; thus, the structure of the tooth crown attains its typical twosegmented appearance. In adults this fold is retained only in some specimens of $O$. dauurica. In other species a superficial furrow can be found occasionally on the lingual side of $\mathrm{p} 3$, but its rounded edges differ from those of juveniles (Fig. 3C). I cannot confirm the observation by Rekovets (1985) that juvenile furrow is frequently present in adult specimens. It is possible that this author treated some subadult pikas with quite formed skulls as adults.

I studied the sample of $O$. alpina, collected in December in the vicinity of Katon-Karagai, South-West Altai. There are no specimens who could be determined as subadult on the basis of the characters described above. However, this sample appeared to be more variable in a number of craniometric features than the sample of over-wintered animals from the same locality (Tab. 1). Over-wintered specimens and subadults are well separated in the space of the principal components axes (Fig. 4). Pikas from the December sample display heterogeneity: some specimens clearly plot out in the same part of the scatter plot as adults, but three specimens take up the extreme location between subadults.

The following results were obtained after comparing the data on post-mortem examination during field investigations with the skeletal condition. Adult over-wintered pikas, which had begun reproducing, but with the open frontoparietal suture were found repeatedly. Such

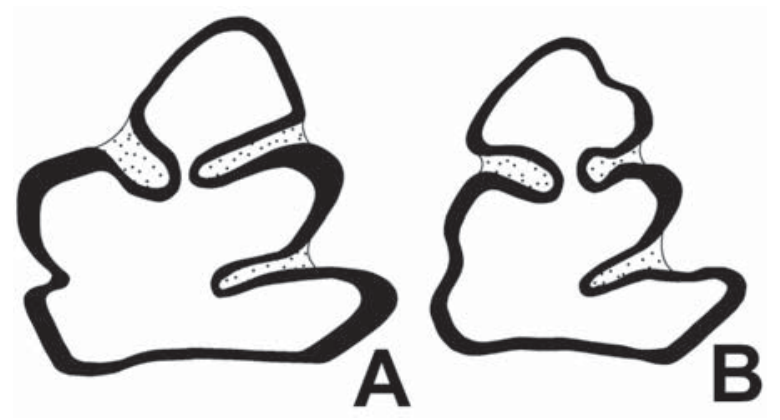

Figure 3. The third lower premolar (p3) of adult pikas with rudiment of lingual loop between middle and posterior tooth segments.

A - Ochotona dauurica; B - Ochotona alpina. 
Table 1. Significance of differences between variances of craniometric features in the samples of over-wintered pikas and specimens, collected in winter.

\begin{tabular}{|l|c|c|c|c|}
\hline Parameters & Over-wintered & Winter sample & $\begin{array}{c}\text { F test (degrees of } \\
\text { freedom df1=7, df2=5) }\end{array}$ & p-level \\
\hline condylobasal length & 1.19 & 5.27 & 4.44 & 0.12 \\
\hline length of palatine foramen & 0.22 & 0.35 & 1.60 & 0.49 \\
\hline diastema length & 0.07 & 0.61 & 9.08 & 0.02 \\
\hline alveolar length of maxillary toothrow & 0.03 & 0.18 & 6.66 & 0.06 \\
\hline rostral length & 0.24 & 1.38 & 5.85 & 0.06 \\
\hline zygomatic breadth & 0.27 & 0.89 & 3.22 & 0.19 \\
\hline postorbital constriction & 0.17 & 0.14 & 1.22 & 0.62 \\
\hline width between lateral edges of auditory bullae & 0.15 & 0.65 & 4.35 & 0.12 \\
\hline skull height & 0.24 & 0.33 & 1.37 & 0.56 \\
\hline
\end{tabular}

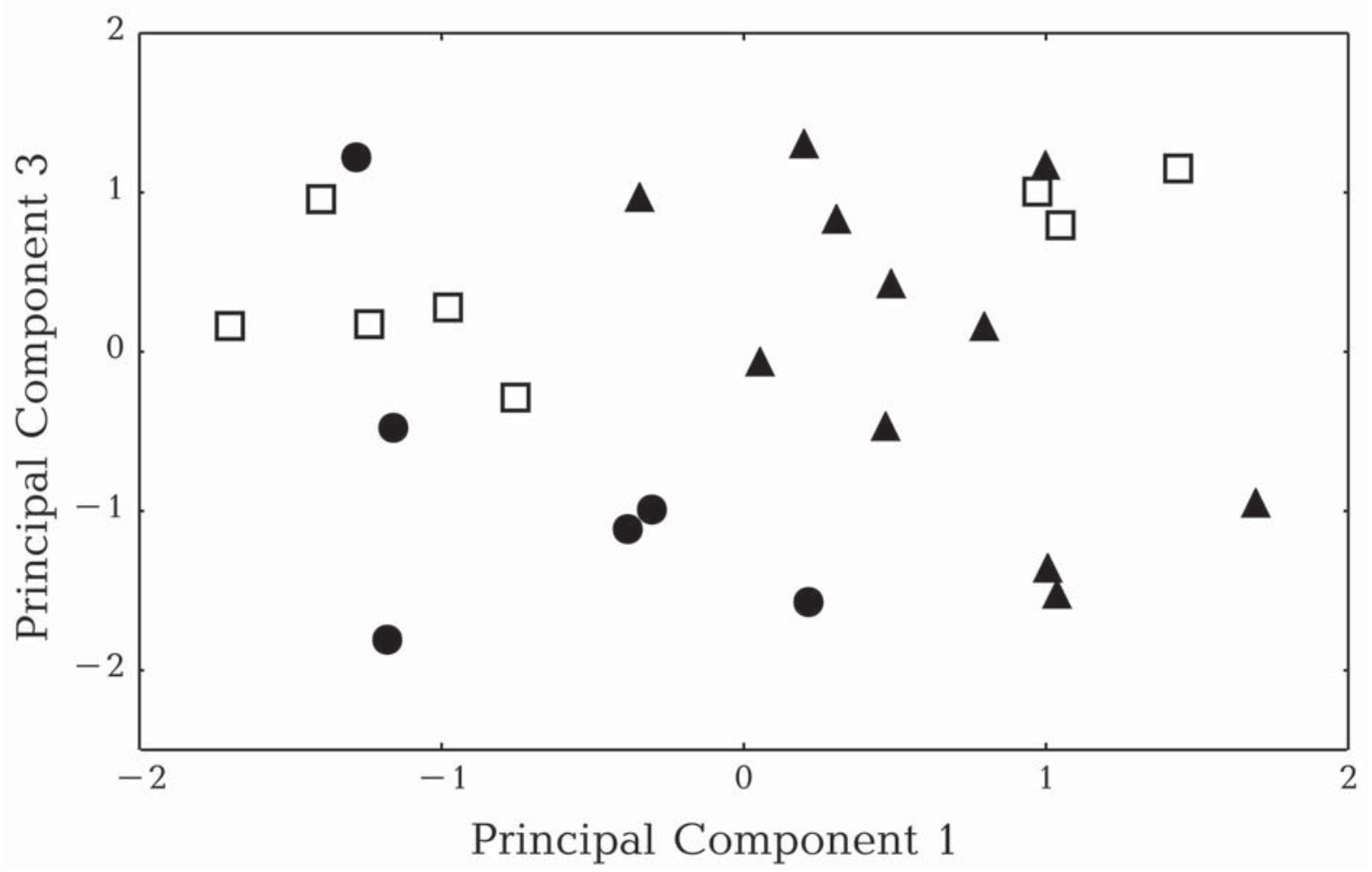

Figure 4. Distribution of Altai pikas of different ages from one locality by craniometric features in the space of the principal components axes (circles — the over-wintered specimens; quadrates — specimens, collected in December; triangles — subadult specimens).

gaps were found in the skulls of specimens of $O$. hyperborea from Zapadnyi Sayan Mountains (S-167267), Krizhin Range (S-170398), Ulan-Burgasy Range (S169107), and Putorana Plateau (S-164032, S-164025, and S-164009). At the same time, other pikas from these samples possess well developed sutures: Zapadnyi Sayan Mountains (S-165398); Krizhin Range (S-170399, S170400); Ulan-Burgasy Range (S-169105, S-169106); Putorana Plateau (S-164013, S-164026). Some speci- mens of $O$. alpina from Zapadnyi Sayan Mountains possess such a gap (S-167265), while the others (S167264, S-167266) lack it; specimens of O. turuchanensis from Putorana Plateau (S-164030, S-164013) have the gap, but in the majority of skulls, for example S162968 and S-164011, it is absent. Quite a common phenomenon is the presence of pikas born in this year, possessing growing premolars and undeveloped crests on the dentary, but with well developed sagittal and 
lambdoid crests of skull, for example specimens S171513, S-171516 and S-161358 from Altai Mountains. Practically all adult pikas collected by me during the summer season were undergoing molt $(n=65)$. We captured only one adult female of $O$. hyperborea without any traces of molt on July 4, 1996. Post-mortem examination revealed that this animal did not begin reproduction in that year.

\section{Discussion}

We may suggest that the decrease in the proportion of specimens with undeveloped crest for attaching $\mathrm{m}$. masseter lateralis profundus corresponds to the period of maturation and formation of the crest in juvenile pikas. Assuming that the rate of crest formation is relatively constant, the specimens with the latest formation of the crest should correspond to the youngest animals from the last litter. Comparing the time of disappearance of specimens with undeveloped crests and dates of reproduction in pikas (Sokolovet al., 1994), we can calculate an approximate age when the crest reaches its adult state. In this case the disappearing of specimens with undeveloped crests takes place approximately about four months after the birth of the last litter in all the species. This age corresponds with data of Sapargeldyev (1987) onO. rufescens and Gashev (1966) on O. hyperborea. Bernstein \& Klevezal (1965) agreed that the majority of cranial features in $O$. rutila and $O$. macrotis are developed up to the age of 3.5-4 months. Otherwise Bernstein (1964) and Bernstein \& Klevezal (1965) supposed that the rate of crest formation is not constant, because it develops as a response to the shift to a more roughage diet in the winter. However, such assumption cannot explain the decrease in the proportion of specimens with undeveloped crest in the autumn.

The degree of skull ossification and closing of the skull sutures cannot be applied in age determination, due to the occurrence of over-wintered and reproducing specimens with open sutures and commonness of clearly young pikas with fully developed sagittal and lambdoid crests. Hence these features have not predictable demonstrations.
One may assess the time of replacement of the first dental generation by evaluating the age of young animals possessing the final stage of replacement. This evaluation may be suggested by body weights (Tab. 2). Thus the replacement of $\mathrm{p} 3$ takes place approximately near the age of one month. Probably, the replacement of P2 takes place several days later. The data of Gashev (1966) concerning the late replacement of $\mathrm{I} 2$ relatively to premolars cannot be confirmed by our data. From the moment of teeth replacement to the time of wearing out of the prismatic part of the crown we can use the existence of the lingual fold between middle and posterior segments of $\mathrm{p} 3$ as the age criterion. However, as long as wearing out of the prismatic part of the crown and the development of the crest on the mandible take place simultaneously, this feature does not make any significant contribution to age determination using the whole skull.

In spite of Gashev's (1966) skepticism, the pelage condition can be used for the age determinations of pikas in summer. Seasonal molt takes place in pikas two times per year (Kapitonov, 1961; Bernstein, 1970; Gashev, 1971; Tavrovskii, 1971; Smith \& Weston, 1990; Sokolov et al., 1994). The timing of molts varies, depending on particular climate conditions; often the spring and autumn molts are not separated in time. A new-born pika also undergoes molt twice. First it changes juvenile fur to summer adult pelage, then the common autumn molt begins. It is quite difficult to distinguish post-juvenile and autumn molts in pikas born late in the summer (Gashev, 1971; Tavrovskii, 1971). Molting proceeds in the nasocaudal direction (Kapitonov, 1961; Tavrovskii, 1971; Sokolov et al., 1994); in some cases diffuse postjuvenile molt is reported(Bernstein, 1970; Sapargeldyev, 1987; Smith \& Weston, 1990). Despite the seemed difficulty, it is always possible to determine which type of molt takes place with a particular individual. The spring molt of an over-wintered animal is characterized by the existence of regular and relatively short summer fur on the anterior part of body and tousled and long hairs on the backside. Post-juvenile molt looks conversely: short, usually more grayish juvenile pelage on the posterior part of body is being replaced by longer summer fur from the front. The autumn molt proceeds in a similar

Table 2. Body mass of young pikas possessing both generations of $\mathrm{p} 3$ simultaneously (A, our samples), compared to the body mass of animals with known age (B).

\begin{tabular}{|l|c|c|}
\hline Species (locality) & A, in $\mathrm{g}$ & $\mathrm{B}$ \\
\hline O. hyperborea (Chukotka Peninsula and Polar Ural) & $34.5 ; 25.9 ; 25.7 ; 43.3 ; 34$ & $\begin{array}{c}16 \text { days }-32-33 \mathrm{~g} \\
* 33 \text { days }-70 \mathrm{~g} *\end{array}$ \\
\hline O. alpina (Zapadnyi Sayan) & $82 ; 100 ; 76$ & - \\
\hline O. pusilla (Kazakhstan) & 55 & 20 days $-44 \mathrm{~g}^{* *}$ \\
\hline O. dauurica (Tuva and Transbaikalia) & $52 ; 27 ; 42 ; 15.5$ & - \\
\hline O. pallasi (Kazakhstan) & 50 & 10 days $-16-18 \mathrm{~g} * * *$ \\
\hline
\end{tabular}

* after Gashev (1971).

** after Shubin (1965).

*** after Smirnov (1972). 
pattern in pikas of all ages, therefore it is useless for age determination. Absence of any molt during the summer period is typical for subadult animals which had molted into adult fur already. This rule, however, has exceptions, such as the event on the Putorana plateau described above. This fact confirms once more that delay in the termination of spring molt is connected with high energy consumption associated female reproduction (Gashev, 1971). Also, I cannot exclude the possibility of occurrence of adult pikas without traces of molt visible on the inner surface of their hide in late summer.

Age determination using the condition of the reproductive system is possible only during a short period in summer. Firstly, the reproductive period in pikas is quite prolonged, and not all the individuals begin mating simultaneously. As a result, one may catch pikas of the same age with active and passive gonads at the same time. Secondly, the traces of reproduction disappear very quickly both in males and in females (Bernstein, 1964; Gashev, 1966). Taking into consideration that reproduction of pikas born this year is known for a number of species (Tarasov, 1950; Shubin, 1965; Bernstein, 1970; Tavrovskii, 1971; Tretyakov et al., 1989; Smith \& Weston, 1990; Borisova et al., 2001), the condition of the reproductive system is depreciated as a criterion of age determination.

Thus there is no problem in distinguishing a pika born this year from an over-wintered one during the reproductive season. The undeveloped crests on the mandible, the growing premolars, the existence of juvenile fur or the absence of traces of spring molt will show us an individual which was born this year. Those pikas which are in the process of teeth replacement will not be older than 1-1.5 months. Pikas with permanent premolars, but with prismatic $\mathrm{p} 3$ with the characteristic lingual fold between middle and posterior segments will be in the age between 1.5 and 4 months. Animals older than 4 months with well developed crests and teeth practically cannot be distinguished from adults. At the same time such subadult pikas may differ from adults in the skull proportions. This fact must be taken into account when using samples of wintering pikas in taxonomic analysis. It is still impossible to determine the age of overwintered pika. The method of age determination by the number of cement lines in the periostal zone of mandible does not work on northern pikas with known age, kept in the captivity, and is in need of further revision.

ACKNOWLEDGEMENTS. I want acknowledge A.O. Averianov, A.V. Borissenko, I.Ya. Pavlinov and F.Ya. Dzerzhinskii for a number of valuable advises during the preparation of the paper.

\section{References}

Bernstein A.D. 1964. [The reproduction of red pika (Ochotona rutila Sev.) in the Zailiiskii Alatau] // Byulleten' Moskovskogo Obshchestva Ispytatelei Prirody, Otdel Biologicheskiy. T.69. No.3. P.40-48 [in Russian].

Bernstein A.D. 1970. [The ecology of large-eared pika in Tyan'-Shan']//Fauna i Ekologiya Gryzunov. No.9. P.62-
109 [in Russian, with English summary].

Bernstein A.D. \& Klevezal G.A. 1965. [Age determination in Ochotona rutila and O. macrotis] // Zoologicheskii Zhurnal. T.44. No.5. P.787-789 [in Russian, with English summary]. Borisova N.G., Starkov A.I., Sazonov G.I. \& Rudneva L.V. 2001. [On the ecology of the daurian pika in south-western Transbaikalia] // Trudy Zoologicheskogo Instituta RAN. T.288. P.163-179 [in Russian, with English summary].

Gashev N.S. 1966. [On age determination for the pika Ochotona hyperborea Flerov] // Byulleten' Moskovskogo Obshchestva Ispytatelei Prirody, Otdel Biologicheskiy. T.71. No.6. P.24-30 [in Russian, with English summary].

Gashev N.S. 1971. [Northern pika (Ochotona hyperborea Pallas, 1811)] // Trudy Instituta Ekologii Rastenii i Zhivotnykh Ural'skogo Nauchnogo Tsentra Academii Nauk SSSR. T.80. No.1. P.4-74 [in Russian].

Gureev A.A. \& Erbaeva M.A. 1975. [To the diagnostics of deciduous teeth of fossil lagomorphs] // Paleontologicheskii Zhurnal. No.3. P.152-153 [in Russian].

Kapitonov V.I. 1961. [Ecological observations on Ochotona hyperborea Pall. in the lower part of the Lena River] // Zoologicheskii Zhurnal. T.40. No.6. P.922-933 [in Russian, with English summary].

Khmelevskaya N.V. 1961. [About biology of alpine pika] // Zoologicheskii Zhurnal. T.40. No.10. P.1583-1585 [in Russian].

Millar J.S. \& Zwickel F.C. 1972. Determination of age, age structure, and mortality of the pika, Ochotona princeps (Richardson) // Canadian Journal of Zoology. Vol.50. No.2. P.229-232.

Rekovets L.I. 1985. [Microtheriofauna of Desna-Dnepr Late Paleolithic]. Kiev: Naukova Dumka. 166 p. [in Russian].

Sapargeldyev M. 1987. [The ecology of Afghan pika in Turkmenia]. Ashkhabat: Ilim. 144 p. [in Russian].

Shubin I.G. 1965. [The reproduction of steppe pika] // Zoologicheskii Zhurnal. T.44. No.6. P.917-924 [in Russian, with English summary].

Smith A.T. \& Weston M.L. 1990. Ochotona princes // Mammalian Species. No.352. P.1-8.

Smirnov P.K. 1972. [The experience of keeping and breeding of Pallas pika (Ochotona pricei Thom.)] // Vestnik Leningradskogo Gosudarstvennogo Universiteta, Seriya Biologiya. No.15. P.20-26 [in Russian].

Sokolov V.E., Ivanitskaya E.Yu., Gruzdev V.V. \& Heptner V.G. 1994. [Mammals of Russia and Adjacent Regions: Lagomorphs]. Moskva: Nauka. 272 p. [in Russian].

Tarasov P.P. 1950. [To the ecology of Pallas pika] // Byulleten' Moskovskogo Obshchestva Ispytatelei Prirody, Otdel Biologicheskiy. T.55. No.6. P.35-42 [in Russian].

Tavrovskii V.A. (ed.). 1971. [Mammals of Yakutia]. Moskva: Nauka. 176 p. [in Russian].

Tretyakov G.P., Mitropol'skii O.V. \& Foteler E.R. 1989. [To the ecology of red pika in Gissar Range in Uzbekistan] // Uzbekskii Biologicheskii Zhurnal. No.5. P.42-44 [in Russian].

Yurgenson P.B. 1939. [To the ecology of the pika Ochotona alpina Pallas in the Eastern Altai] // V. N. Makarov (ed.). [Scientific and Methodic Notes of the Main Administration on Natural Reserves]. Moskva: Izdatel'stvo Glavnogo Upravleniya po Zapovednikam. No.5. P.122-130 [in Russian]. 